Joanna SZERSZUNOWICZ

\title{
FUNKCJA MOTYWACJI ZNACZENIOWEJ FRAZEOLOGIZMU W PRZEKŁADZIE
}

Translacja w ujęciu Mary Snell-Hornby to kulturowy transfer, do przeprowadzenia którego konieczny jest bilingwizm i bikulturyzm tłumacza ${ }^{1}$. Tekst, artefakt wytworzony przez daną społeczność, zaczyna funkcjonować jako translat w innym kręgu kulturowym. Odbiorca przekładu dysponuje inną wiedzą o świecie niż adresat oryginału. Claire Kramsch zwraca uwagę na wieloaspektowość relacji język - kultura w kontekstach komunikacyjnych $(2000,3)$. Język odzwierciedla rzeczywistość, rejestrując zachodzące w niej zmiany. Utrwalone są one w warstwie leksykalnej języka, a szczególnie ciekawym przykładem zapisu kultury danej społeczności jest frazeologia. Porównanie związków frazeologicznych funkcjonujących w językach oryginału i przekładu z uwzględnieniem motywacji znaczeniowej frazeologizmów ma istotne znaczenie na pierwszym etapie przekładu, którym jest zrozumienie tekstu (Wawrzyniak 2002, 43), a więc odczytanie wszystkich zawartych w nich sensów, danych zarówno implicytnie jak i eksplicytnie. Małgorzata Marcjanik nie bez racji stwierdza, iż komparatystyka frazeologiczna jest interesujacym problemem badawczym między innymi dlatego, że w większym stopniu niż inne dziedziny językoznawstwa odzwierciedla wpływy czynników pozajęzykowych na kształtowanie się języka (1984, 191). Tłumacz musi mieć świadomość funkcji owych czynników pozajęzykowych w danym tekście.

W przypadku frazeologii motywowanej znaczeniowo pojawia się problem relacji między frazeologizmem motywowanym znaczeniowo a ekwiwalentem przekładowym, którym może być forma opisowa bądź

1 Zob. M. Snell-Hornby, Translation Studies. An Integrated Approach, Amsterdam 1988; M. Snell-Hornby, Übersetzenwissenschaft - eine Neueorientierung, Tübingen 1986. 
frazeologizm istniejący w języku przekładu o zbliżonym znaczeniu. Nawet jeżeli w języku przekładu funkcjonuje frazeologizm synonimiczny, ma on $\mathrm{z}$ reguły inną motywację znaczeniową, co może mieć istotne znacznie dla organizacji całego tekstu - informacji, asocjacji i wartości stylistycznej. Przede wszystkim, tłumacz powinien mieć świadomość tego, w jakim stopniu motywacja znaczeniowa frazeologizmu jest czytelna dla rodzimych użytkowników języka. Stopień upowszechnienia pierwotnej motywacji frazeologizmu jest wartością zmienną w czasie oraz zależną od indywidualnej wiedzy natywnego użytkownika języka (Pajdzińska 1988, 483), jednakże jest to wartość podlegająca uśrednieniu poprzez uwzględnienia stopnia znajomości motywacji znaczeniowej przez ogół danej społeczności.

Wnioskować o znajomości motywacji znaczeniowej danego frazeologizmu można na podstawie pewnych czynników. Pierwszym z nich jest obrazowość frazeologizmu, objaśniająca jego proweniencję. Przykładowo, polski zwrot kruszyć o coś kopie ma czytelną motywację znaczeniową dzięki swojej obrazowości. Inaczej jest w przypadku związków frazeologicznych zawierających elementy reliktowe - zwrot zażyć kogoś z mańki ma człon martwy (Lewicki, Pajdzińska 1993, 314).

Do zachowania motywacji znaczeniowej w świadomości użytkowników języka przyczyniają się takie nośniki kultury jak literatura, film czy muzyka. Frazeologizm podać komuś czarnq polewkę ma czytelną motywację znaczeniową dzięki przypisowi zamieszczonemu przez Adama Mickiewicza na końcu utworu: Czarna polewka, podana $u$ stołu paniczowi starającmu się o rękę panny oznaczała rekuzę. Inne synonimiczne zwroty, które były używane w okresie Romantyzmu, na przykład ktoś dał komuś wieniec grochowy czy też ktoś dostat szarq gęś nie funkcjonują we współczesnej polszczyźnie (Lewicki, Pajdzińska 1993, 315).

W angielskim przekładzie Pana Tadeusza polski frazeologizm został przetłumaczony dosłownie na język angielski: Soplica is refused Horeszko's daughter/Horeszkos put black soup in Jacek's platter!, oraz, tak jak $\mathrm{w}$ wersji oryginalnej, opatrzony objaśnieniem Black soup, served at table to a young man suing for a young woman's hand, signified a refusal ${ }^{2}$. Technika

2 Cytaty podaje według A. Mickiewicz, Pan Tadeusz, czyli ostatni zajazd na Litwie. Polish E English text, tłum. K. R. MacKenzie, Londyn 1990. 
przekładowa przyjęta przez tłumacza jest właściwa. W angielszczyźnie istnieją zwroty frazeologiczne o wartości synonimicznej, jednak ich wartość stylistyczna kwalifikuje je jako nieadekwatne ekwiwalenty przekładowe. Ponadto, brak im, wyczuwalnego w polskim zwrocie, zabarwienia archaicznością.

Inne postępowanie przekładowe można zaobserwować $\mathrm{w}$ tłumaczeniu związków frazeologicznych, których motywacja znaczeniowa uległa zatarciu. Stosuje się wówczas tak zwane tłumaczenie "omowne" lub dobiera się rodzimy frazeologizm o zbliżonym znaczeniu. Słownik idiomów angielskich autorstwa Piotra Borkowskiego podaje dwa warianty polskich ekwiwalentów przekładowych frazeologizmu when Queen Anne was alive. Pierwszy $\mathrm{z}$ nich, stanowi egzemplifikację tłumaczenia "omownego" - za dawnych czasów, drugi zaś jest frazeologizmem polskim za króla Ćwieczka (1991, 160). Tłumacz dokonuje wyboru odpowiednika w języku polskim zależnie od kontekstu, w jakim frazeologizm ma być użyty.

Dobór ekwiwalentu przekładowego frazeologizmu motywowanego znaczeniowo powinien być wynikiem wieloaspektowej analizy motywacji obejmującej takie elementy, jak nośność informacji, wywoływanie określonych asocjacji $u$ odbiorcy oraz wartościowanie wpisane $\mathrm{w}$ motywację, a w związku z tym wartość stylistyczna przypisywana frazeologizmowi. W celu zilustrowania powyższej konstatacji, przeanalizujmy angielski frazeologizm $a$ winter of discontent. Oznacza on trudną sytuację polityczną w okresie zimy, zwłaszcza strajki w najważniejszych gałęziach sektora publicznego. Pierwotnie wyrażenie a winter of discontent odnosiło się do zimy 1978-79 w Wielkiej Brytanii, kiedy miały miejsce bardzo poważne strajki. Wyrażenie to ma proweniencję literacką, pochodzi bowiem ze sztuki Szekspira Ryszard III (Oxford Guide $1999,586)^{3}$.

3 Now is the winter of our discontent/Made glorious summer by this sun of York pochodzi $\mathrm{z}$ The Tragedy of King Richard the III, Act I, Scene I Williama Szekspira, podaje według wydania The Complete Works of William Shakspeare, London 1992, s. 596; w polskim przekładzie L. Urlicha: Dziś zimy naszej zmienia się niełaska/Na złote lato przy Yorka słońcu, podaję według W. Szekspir, Kroniki, Warszawa 1981, s. 1057. 
Frazeologizm ten wywołuje u Brytyjczyka wiele skojarzeń występujących na różnych płaszczyznach: politycznej, gospodarczej i literackiej. Asocjacje mogą występować w skali mikro - chodzi tu o pryzmat osobistych doznań oraz makro - globalne odniesienia do rzeczywistości. Te dwie kategorie mają charakter komplementarny i współtworzą całościowy system asocjacji wywołanych $u$ Brytyjczyka. Skojarzenia adresata komunikatu, w którym wystąpił ten frazeologizm uwarunkowane są również jego wykształceniem. W przypadku literackiej proweniencji wyrażenia, mamy bowiem do czynienia $z$ realiami erudycyjnymi. Jak pisze Teresa Micewicz, aluzja historyczna czy też literacka przeznaczone sq dla wykształconego czytelnika i nie sq zrozumiałe niejednokrotnie nawet dla odbiorcy pierwotnego $(1971,118)$. Odbiorca wtórny nie zna faktów historycznych powszechnie znanych mieszkańcom Wielkiej Brytanii. Niezależnie od indywidualnych skojarzeń, wyrażenie a winter of discontent, jako związek frazeologiczny, ma zabarwienie emocjonalne, które ginie w przekładzie.

Znajomość motywacji znaczeniowej często jest niezbędna do właściwego odczytania wartości stylistycznej danego frazeologizmu. Niestety, nie zawsze słowniki frazeologiczne, zwłaszcza mniejsze objętościowo, zawierają kwalifikatory, co znacznie utrudnia pracę tłumacza. Angielskie wyrażenie beyond the Pale, pochodzące z XII wieku, pierwotnie odnosiło się do obszaru poza the Pale, czyli terenu wokół Dublina, na który - za czasów Henryka II - przybyli angielscy osadnicy i gdzie, w konsekwencji kolonizacji, przestrzegane było prawo angielskie. Frazeologizm ten określa dziś zachowania wykraczające poza ogólnie przyjęte normy (Allen, Smith 1995, 103). Natywni użytkownicy języka odbierają to wyrażenie jako obraźliwe. Faktu tego nie rejestruje Longaman Dictionary of English Idioms, chociaż podaje genezę wyrażenia $(1989,246)$. Frazeologizm beyond the Pale jest przykładem wartościowana wpisanego w kulturę. Wydaje się, iż użycie tego wyrażenia wymaga amplifikacji wewnątrztekstowej lub eksplikacji $\mathrm{w}$ przypisie. Warto nadmienić, że $\mathrm{w}$ angielszczyźnie funkcjonują dwie konkurencyjne nazwy tego terenu, mianowicie the English Pale oraz the Pale of Dublin (James 1996, 110, 252). Istnienie dwóch nazw jest odzwierciedleniem odmiennego postrzegania historii przez Irlandczyków i Anglików. 
Również frazeologizmy o zatartej motywacji znaczeniowej mogą sprawiać problemy w przekładzie. Angielski zwrot to be tied to someone's apron string pierwotnie dotyczył prawa angielskiego zwanego apron-string tenure, które stanowiło prawo męża do własności przekazanej przez rodzinę żony (Freedman 1996, 115). Pierwotna motywacja znaczeniowa nie jest czytelna dla współczesnych użytkowników angielszczyzny, nie podają jej też słowniki frazeologiczne języka angielskiego. Zwrot to be tied to someone's apron string tłumaczony jest na język polski jako trzymać się maminego fartucha/fartuszka, spódnicy. Zarówno w angielskim, jak i polskim frazeologizm ten wyraża zależność mężczyzny od kobiety (matki lub żony). Collins Cobuild Dictionary of Idioms rejestruje możliwość wystąpienia zwroty $\mathrm{w}$ połączeniu $\mathrm{z}$ rzeczownikami takimi jak kraj lub instytucja. Ponadto, słownik podaje zwrot cut the apron strings, który nie ma odpowiednika w języku polskim (Collin Cobuild 1997, 8). Użytkownicy języka angielskiego przestali odczuwać dwuplanowość semantyczną zwrotu, czyli przestała dla nich istnieć relacja między znaczeniem dosłownym a przenośnym, dlatego $w$ angielszczyźnie pojawiły się korzystniejsze warunki dla rozwoju tego frazeologizmu niż w języku polskim (Pajdzińska 1988, 486).

Kolejnym problemem przekładu wyrażeń frazeologicznych jest modyfikacja związków frazeologicznych ${ }^{4}$. Modyfikacja realizuje się poprzez innowację, czyli przekształcenia strukturalne oraz defrazeologizację. Najczęściej stosowanym rodzajem modyfikacji jest substytucja jednego $\mathrm{z}$ komponentów, która prowadzi do reinterpretacji połaczenia, zestawienia postaci tradycyjnej i zmodyfikowanej (Stawnicka 2000, 208). W wyniku innego niż utarte zestawienia komponentów powstaje złożony układ odniesień. W angielskim wyrażeniu winter of discontent słowo winter (zima) zastępowane bywa nazwami pozostałych pór roku, zależnie od okresu, w którym mają miejsce strajki. Słownik Longman Dictionary of English Language and Culture rejestruje połączenie summer of discontent, jako pierwotnie użyte $w$ odniesieniu do strajków, które miały miejsce w 1989 (1992, 1329). Pozostałe słowniki idiomów i leksykony kultury

4 Zob. E. Rechtsiegel, O przekładzie modyfikacji zwiq̨zów frazeologicznych (na materiale języka polskiego i niemieckiego), "Poradnik Językowy" 1985, z. 3, s. 358-364; S. Bąba, Modyfikacje utartych związów wyrazowych we wspótczesnej fraszce polskiej, „Poradnik Językowy” 1971, z 8, s. 444-452. 
angielskiej wydawnictwa Longman nie rejestrują wyrażenia summer of discontent, podając jedynie winter of discontent.

Słownik idiomów wydawnictwa Oxford również zawiera przykłady modyfikacji związków frazeologicznych, na przykład w haśle the Hungry Forties (dosł. głodne lata czterdzieste - ciężki okres w XIX wieku w Wielkiej Brytanii, kiedy głodowano z powodu wysokich cen mąki i chleba) podana jest również modyfikacja the hungry thirties (dosł. głodne lata trzydzieste) (Cowie, Mackin, McCaig 1994, 292). Z translatorycznego punktu widzenia taki sposób podawania wyrażeń i zwrotów frazeologicznych jest bardzo korzystny dla tłumacza, ponieważ ułatwia mu deszyfrację frazeologizmu $\mathrm{w}$ zmienionej postaci. Tłumaczenie innowacji frazeologicznej o czytelnej motywacji znaczeniowej wydaje się być bardziej skomplikowanym procesem translatorskim. Pojawia się nowy sens, który powstaje $\mathrm{w}$ wyniku współistnienia $\mathrm{w}$ świadomości odbiorcy komunikatu znajomości motywacji, właściwego znaczenia frazeologizmu oraz nowego, zmodyfikowanego znaczenia. Oddanie owego sensu wymaga często amplifikacji. Jeżeli chodzi o frazeologizmy o zatartej motywacji znaczeniowej, w przekładzie powinien pojawić się zmodyfikowany frazeologizm istniejący $\mathrm{w}$ języku przekładu. Wszystkie innowacje frazeologiczne należą do wyjątkowo trudnych jednostek przekładowych.

Za takie należy również uznać związki frazeologiczne, w których eliminacji ulega człon fakultatywny semantycznie. Zjawisko eliminacji takiego członu ma miejsce najczęściej w strukturach o dużym stopniu leksykalizacji frazeologicznej. Zdarza się, iż redukcji ulega człon, który nie jest fakultatywny, a tworzy związek współrzędny. W języku angielskim istnieje wyrażenie hawks and doves (dosł. jastrzębie i gołębie) określające dwa różne nastawienia do polityki - pierwsze $\mathrm{z}$ nich, drapieżne, aprobujące prowadzenie wojny, drugie - optujące za pokojowym rozwiązaniem konfliktów. Wyrażenie to było często używane przez Amerykanów w okresie wojny w Wietnamie. Aktualnie funkcjonuje ono $\mathrm{w}$ postaci hawks and doves, ale człony składowe wyrażenia używane są także osobno. Ponadto, na uwagę zasługuje fakt, iż słowniki rejestrują derywaty utworzone od wyrazów hawk i dove, których znaczenie pozostaje $\mathrm{w}$ ścisłym związku z pierwotną motywacją znaczeniową, na przykład hawks/hawkish/hawkishness. 
Ścisłe związki języka i kultury bywają źródłem problemów związanych z przekładem. $Z$ całą pewnością zasób frazeologiczny języka jest nośnikiem przekazu kulturowego, zwłaszcza w przypadku tych frazeologizmów, których motywacja znaczeniowa jest czytelna dla rodzimych użytkowników języka oryginału. Wartość konotacyjna takich wyrażeń i zwrotów frazeologicznych może być w niektórych przypadkach bardziej istotna dla tekstu niż wartość leksykalna. $Z$ tego powodu, translat zawierający takie frazeologizmy ulega często rozbudowaniu $w$ stosunku do tekstu oryginału.

Rekapitulując, należy stwierdzić, że frazeologia jest potencjalnym nośnikiem nieprzekładalności. Dotyczy to w szczególności tych jednostek frazeologicznych, których motywacja jest znana użytkownikom danego języka. W przypadku przekładu frazeologizmów motywowanych znaczeniowo warta odnotowania jest konstatacja Henryka Lebiedzińskiego, który stwierdza, że powiedzenia $w$ rodzaju "Wyszedł jak Zabłocki na mydle", "Plecie jak Piekarski na mękach" nie mogq być ekwiwalentem: sq zbyt konkretnie polskie, by równoważyć, na przykład japońskie (1989, 241). Referencja kulturowa zastąpiona bywa referencją wypowiedzeniową. Ten sposób tłumaczenia w przypadku frazeologizmów może być wyzyskany w przypadku zatarcia się motywacji znaczeniowej danego wyrażenia czy zwrotu. Należy podkreślić, że frazeologia, niezależnie od stopnia czytelności motywacji, sprawia trudności w przekładzie. Świadczy o tym liczba błędów w tłumaczeniach. $\mathrm{W}$ podsumowaniu przeprowadzonych niedawno badań Zofia Kozłowska stwierdza, iż najliczniejszq grupę stanowiq błędy frazeologiczne $(2001,141)^{5}$. Należy więc poświęcić więcej uwagi przekładowi frazeologii, uwzględniając różne aspekty tłumaczenia.

\section{Literatura}

Allen D., Smith P., 1995, Life and Culture in the English Speaking World, Milano.

\footnotetext{
5 Autorka przeanalizowała 70 prac studentów IV roku ILS z I i II językiem rosyjskim (drugi rok nauczania tłumaczenia).
} 
Bąba S., 1971, Modyfikacje utartych zwiqzków wyrazowych we współczesnej fraszce polskiej, "Poradnik Językowy” z. 8, s. 444-452.

James E., 1996, NTC's Dictionary of the United Kingdom, Lincolnwood.

Kozłowka Z., 2001, O błędach językowych w tekstach polskich przekładów, [w:] Język rodzimy a język obcy. Komunikacja, przekład, dydaktyka, red.

A. Kopczyński, U. Zaliwska-Okrutna, Warszawa, s. 137-147.

Kramsch C., 2000, Language and Culture, Oxford.

Lebiedziński H., 1989, Przekładoznawstwo ogólne wobec teorii enroi, Warszawa.

Lewicki A. M., Pajdzińska A., 1993, Frazeologia, [w:] Encyklopedia kultury polskiej XX wieku. Wspótczesny język polski, t. II, red. J. Bartmiński, Wrocław, 307-327.

Longman Dictionary of English Language and Culture, 1992, Harlow.

Marcjanik M., 1984, Idiomatyczne zwiazki frazeologiczne $w$ języku rosyjskim i polskim, [w:] Studia i materiały XIII. Filologia polska 4, Zielona Góra, s. 187-1999.

Micewicz T., 1971, Zarys teorii przekładu, Warszawa.

Oxford Guide to British and American Culture, 1999, Oxford.

Pajdzińska A., 1988, Frazeologia a zmiany kulturowe, "Poradnik Językowy”, z. 7 , s. $480-487$.

Stawnicka J., 2000, Innowacje frazeologiczne we wspótczesnych nagłówkach prasowych, [w:] Język trzeciego tysiąclecia, red. G. Szpila, Kraków, s. 207-215.

Wawrzyniak Z., 2002, Zasady rozumienia jako warunki konstytutywne tłumaczenia, [w:] Recepcja. Transfer. Przekład, red. J. Koźbiał, Warszawa, s. 39-47.

\section{Opracowania słownikowe}

Bąba S., Liberek J., 2002, Słownik frazeologiczny wspótczesnej polszczyzny, Warszawa.

Cambridge Inernational Dictionary of Idioms, 1998, Cambridge.

Collin Cobuild Dictionary of Idioms, 1997, London.

Cowie A. P., Mackin R., McCaig I. R., 1994, Oxford Dictionary of English Idioms, Oxford.

Głowińska K., 2000, Popularny słownik frazeologiczny, Warszawa. 
Gulland D. M., 2002, Langenscheidt 1000 idiomów angielskich, Warszawa.

Gulland D. M., Hinds-Howell D. G., 1994, The Penguin Dictionary of English Idioms, London.

Freedman T., Freedman D., 1996, The Wordsworth Dictionary of Cliché, Ware.

Jaworska T., 1999, Stownik frazeologiczny polsko-angielski, Warszawa.

Kakietek P., 1993, Polsko-angielski słownik frazeologiczny, Warszawa.

Longman Dictionary of English Idioms, 1989, London.

Simbierowicz L., 2000, Nowy angielsko-polski słownik idiomów i zwrotów, Warszawa.

Skorupka S., 1999, Stownik frazeologiczny języka polskiego, Warszawa.

Stownik idiomów angielskich, 1993, red. J. Fisiak, Warszawa.

Stownik idiomów angielskich ... od Acid test do Zero hour ..., 1999, tłum.

M. Tkaczyk, Warszawa. 